\title{
A COMPARATIVE ANATOMICAL AND BIOCHEMICAL ANALYSIS IN SALSOLA (CHENOPODIACEAE) SPECIES WITH AND WITHOUT A KRANZ TYPE LEAF ANATOMY: A POSSIble REVERSION OF $\mathrm{C}_{4}$ TO $\mathrm{C}_{3}$ PHOTOSYNTHESIS ${ }^{1}$
}

\author{
Vladimir I. P'yankov, ${ }^{2}$ Elena V. Voznesenskaya, ${ }^{3}$ Alexandra V. \\ Kondratschuk, ${ }^{2}$ and Clanton C. Black, JR. ${ }^{4,5}$ \\ ${ }^{2}$ Plant Physiology and Biochemistry Department, Urals State University, Lenin Avenue 51, \\ 620083 Ekatherinburg, Russia; \\ ${ }^{3}$ Morphology and Anatomy Department, Komarov Botanical Institute, Prof.Popov Street 2, \\ 197376 St.-Petersburg, Russia; and \\ ${ }^{4}$ Biochemistry and Molecular Biology Department, University of Georgia, Life Sciences Building, Athens, Georgia 30602
}

\begin{abstract}
Leaf anatomy was studied by light and electron microscopy and the leaf activities of RUBP carboxylase, PEP carboxylase, and malic enzyme were assayed in: Salsola australis and S. oreophila grown on the West Pamirs at $1800 \mathrm{~m}$ altitude; in $S$. australis grown on the East Pamirs at $3860 \mathrm{~m}$; and in S. arbusculiformis grown in the Kisil-Kum desert in Middle Asia near $500 \mathrm{~m}$. Carbon isotope fractionation ratio values also were measured on whole leaf tissue for 18 Salsola species field collected in these and other regions of the former USSR. S. australis leaves are cylindrical and in cross section exhibit a peripheral ring of mesophyll and then an inner ring of bundle sheath type cells; and its biochemical characteristics and $\delta^{13} \mathrm{C}$ values are typical of a $\mathrm{C}_{4}$ species of the NADP-malic enzyme malate-forming group. These traits were expressed independent of the plant growth altitude up to $4000 \mathrm{~m} . \mathrm{C}_{4}$ type $\delta^{13} \mathrm{C}$ values were obtained in 14 of the Salsola species.

Anatomical, structural, and biochemical features typical of the $\mathrm{C}_{4}$ syndrome were absent in $S$. oreophila and $S$. arbusculiformis. Four Salsola species, including these two, had $\mathrm{C}_{3}$-type $\delta^{13} \mathrm{C}$ values. Their cylindrical leaves in cross section exhibited two to three peripheral rings as layers of palisade parenchyma. Although their vascular bundles were surrounded by green bundle sheath cells, their organelle numbers were comparable to those in mesophyll cells. Neither bundle sheath cell wall thickenings nor dimorphic chloroplasts in two leaf cell types were observed. In $S$. oreophila, there was a high activity of RuBP carboxylase, but a low activity of $\mathrm{C}_{4}$ cycle enzymes. Interpretation of these data lends evidence to the hypothesis that a small group of $\mathrm{C}_{3}$ Salsola species, including $S$. oreophila, S. arbusculiformis, S. montana, and $S$. pachyphylla, arose as the result of a reversion of a $\mathrm{C}_{4}$ to a $\mathrm{C}_{3}$ type of photosynthetic $\mathrm{CO}_{2}$ fixation in the cooler climates of Middle Asia.
\end{abstract}

Key words: $\mathrm{C}_{3}$ and $\mathrm{C}_{4}$ photosynthesis; $\mathrm{C}_{4}$ enzymes; Kranz anatomy; malic enzyme; Middle Asia; RuBP carboxylase; Salsola.

Most Salsola species and taxa of the tribe Salsoleae of the family Chenopodiaceae have a $\mathrm{C}_{4}$ type of photosynthesis (Olesen, 1974; Carolin, Jacobs, and Vesk, 1975; Winter, 1981; Zalenskii and Glagoleva, 1981; Gamaley and Voznesenskaya, 1986; Piankov and Vakhrusheva, 1989; P'yankov, 1991). As a rule they have what is called "Salsoloid" (Carolin, Jacobs, and Vesk, 1975) or a "Crownary-centrical" Kranz type of photosynthetic cell arrangement (Vosnesenskaya and Gamaley, 1986), which can occur either in succulent cylindrical leaves or in stems of aphyllous species. In this type of Kranz or "garland" structure, mesophyll and pronounced bundle sheath type cells form continuous green rings around the leaf (or stem) periphery with their central part mostly occupied by water-storing parenchyma and vascular tissues. A similar type of photosynthesis and cellular ultrastructure has been reported in other species such as Suaeda monoica (Shomer -Ilan, Beer, and Waisel, 1975) and Portulaca grandiflora. Often such plants exhibit the NADPmalic enzyme biochemical type of photosynthetic carbon metabolism with a characteristic expression of either $\mathrm{C}_{4}$

\footnotetext{
${ }^{1}$ Manuscript received 21 August 1995; revision accepted 8 October 1996.

${ }^{5}$ Author for correspondence.
}

or $\mathrm{C}_{3}$ enzymes in two specific green cell types ( $\mathrm{Ku}$ et al., 1981; Campbell and Black, 1982).

In Salsola, however, some species have a different cross-sectional leaf anatomy, for example, Carolin, Jacobs, and Vesk (1975) described S. webbii as lacking a Kranz or garland type anatomy, although it had two peripheral layers of palisade parenchyma cells with minor veins below. The central bundle was embedded in waterstoring tissue, and minor vein bundle sheath cells had poorly developed chloroplasts. They considered it an example of a reversion to nonKranz anatomy in Salsola. Such features also were encountered in the genus Sympegma and were designated as "Sympegmoid." Butnik (1984) referred to this structural type as "Centrical Kranz-discontinuous" and characterized it as having a two- to three-layered palisade parenchyma and a discontinuous Kranz bundle sheath. She proposed that these plants were $\mathrm{C}_{4}$ and that this cell arrangement was a predecessor of the Salsoloid type anatomy in the evolution of the $\mathrm{C}_{4}$ Kranz syndrome in Salsola. But neither report presented biochemical, physiological, or isolated cell type data to assess the degree of $\mathrm{C}_{4}$ or $\mathrm{C}_{3}$ photosynthesis in these species.

The first aims of this work were to conduct a quanti- 
tative comparative anatomical analysis of green leaf cells and to determine the biochemical activity of some $\mathrm{C}_{4}$ and $\mathrm{C}_{3}$ photosynthesis enzymes in leaves from field-grown Salsola species, one with a Kranz type of leaf anatomy, S. australis L., and two with an unusual leaf structure of the Sympegmoid type, $S$. oreophila Botsch. and $S$. arbusculiformis Drob. Another aim was to collect leaf material from these and a larger group of Salsola species at natural sites from across the former USSR and to determine their photosynthetic carbon isotope fractionation as another measurement of $\mathrm{C}_{4}$ vs. $\mathrm{C}_{3}$ photosynthesis. A final aim was to integrate the results here with earlier work on Chenopodiaceae systematics and evolution, particularly the work by Botschantzev $(1969,1976)$ and Carolin, Jacobs, and Vesk (1975), to present support for the hypothesis that a reversion of $\mathrm{C}_{4}$ to $\mathrm{C}_{3}$ photosynthesis occurred within Salsola.

\section{MATERIALS AND METHODS}

The anatomical studies were carried out on plant materials collected on the West Pamirs in the valley of the Vanch River at $1800 \mathrm{~m}$ altitude (S. australis L., S. oreophila Botsch.); on the East Pamirs in the valley of the Chechecty River at $3860 \mathrm{~m}$ altitude (S. australis L.); and in the Kisil-Kum desert in Middle Asia (Uzbekistan) at near $500 \mathrm{~m}$ altitude (S. arbusculiformis Drob.). With each plant the leaf chlorenchyma ultrastructure was examined using conventional light microscopy (LM) and transmission electron microscopy (TEM) techniques. For TEM, leaf segments were fixed in glutaraldehyde, postfixed in osmium tetroxide, and then embedded in a mixture of Epon and Araldite. Leaf cross sections were cut with an ultratome Ultracut E (Reichert, Austria), stained with lead citrate, and micrographs were made with a Hitachi H-600 electron microscope (Japan). Assays of RuBP carboxylase (EC 4.1.1.39) (RuBPC), PEP carboxylase (EC 4.1.1.31) (PEPC), and NADP-malic enzyme (EC 1.1.1.40) (NADP-ME) were performed with crude desalted leaf extracts (P'yankov et al., 1991). Chlorophyll contents were measured spectrophotometrically in $80 \%$ acetone whole-leaf extracts. Some quantitative characteristics of leaf structures were determined according to the procedures developed by Mokronosov (1981). This analysis yields a quantitative anatomical comparison of photosynthetic tissues that can be used in comparative physiological and ecological studies. Unfortunately an English translation is not available, but the procedures involve the measurement of specific leaf mass, and leaf, cell, and organelle surfaces, volumes, layers, and numbers. Carbon isotope fractionation ratio values $\left(\delta^{13} \mathrm{C}, \%\right.$ ) were determined on dried whole-leaf or stem material from field-grown plants using standard procedures relative to a PDB (PeeDee belemite) limestone carbon isotope standard (Bender et al., 1973). These photosynthetic materials were collected in various regions of the former USSR in the years given in the results (see Table 4) and air dried for later analysis. Voucher plant specimens are on file at the Komarov Botanical Institute.

\section{RESULTS}

$C_{4}$ photosynthesis in Salsola-Salsola australis has cylindrical leaves with a Salsoloid or Crownary-centrical type of leaf anatomy in cross section. There are two layers of chlorenchyma on the leaf periphery, one layer of elongated palisade parenchyma cells, and one layer of roundish bundle sheath cells (Figs. 1, 2). The main vascular bundles are in the center of the leaf and the chlorenchyma are only in contact with small peripheral bundles. S. australis leaves are characterized by well-developed grana in mesophyll chloroplasts (Figs. 3, 4) and a reduction of grana in bundle sheath chloroplasts (Figs. 5,
6; Tables 1, 2). The bundle sheath cell organelles are in a centripetal position.

Our investigations also show that $S$. australis ecotypes from different altitudes both have a similar leaf structure, though some quantitative differences exist (Figs. 1, 2; Tables 2, 3). For example, plants from $3860 \mathrm{~m}$ exhibited a larger mesophyll cell volume, a lower number of cells per unit of leaf surface, a lower specific leaf mass, a lower chloroplast membrane surface, and a much lower percentage of chloroplast volume per cell volume. However, the number of chloroplasts in each cell type remained nearly constant as did their chloroplast ultrastructure. We found that mesophyll vs. bundle sheath chloroplasts of $S$. australis exhibit a dimorphism characteristic of $\mathrm{C}_{4}$ NADP-ME plants. But mesophyll chloroplasts of high mountain plants have many small grana (of 2-5 thylakoids) with a low length of intergranal thylakoids, while at lower altitudes there are larger grana (of 6-12 thylakoids) with an intensive development of intergranal thylakoids (Figs. 3-6, Table 1). Thus the mesophyll chloroplast granality was slightly lower in high mountain plants, with an equal value in bundle sheath chloroplasts (Table 2). However, the size of organelles was different: both chloroplasts and mitochondria are larger in high mountain plants in both cell types than at lower altitudes (Table 2).

In the photosynthetic enzyme studies $S$. australis leaves exhibited a high activity of PEPC and NADP-ME (Table 3). With an increase in altitude the level of RuBPC and NADP-ME activity significantly increased, and the activity of PEPC decreased. In spite of these changes there is no doubt that $S$. australis is a $\mathrm{C}_{4}$ species of the NADP-ME group. Even with these differences in structure and enzyme activities, when $\delta^{13} \mathrm{C}$ values for carbon isotope fractionation were determined, $S$. australis also was shown to be $\mathrm{C}_{4}$, independent of growth altitude (Table 4). In addition $C_{4}$-type $\delta^{13} \mathrm{C}$ values were obtained for 14 Salsola species in plant samples collected in various regions of the former USSR and in various years (Table 4). Using herbarium materials, Winter (1981) listed 45 other Salsola species with $\mathrm{C}_{4}$-like $\delta^{13} \mathrm{C}$ values. So it seems likely that a high percentage of the $\approx 170$ Salsola species are $\mathrm{C}_{4}$ plants.

$C_{3}$ photosynthesis in Salsola-However, a small group of Salsola likely are $\mathrm{C}_{3}$ plants. In our studies $S$. oreophila had cylindrical leaves but with 2-3 peripheral layers of palisade parenchyma with adjacent small vascular bundles underlying them. These bundles were surrounded by thin-walled parenchyma cells with numerous chloroplasts, which tend to be in a centrifugal position (Figs. $7,8)$. The number of chloroplasts in bundle sheath cells was practically equal to those of palisade mesophyll cells (Table 3). The roundish bundle sheath chloroplasts were somewhat smaller than mesophyll chloroplasts, but their size of grana, and granality, were practically identical (Figs. 9, 10; Tables 1, 2).

A quantitative structural analysis in the two $\mathrm{C}_{3}$-like Salsola species shows that although the bundle sheath cells of $S$. oreophila contain a fairly large number of chloroplasts, they are not as numerous as in the bundle sheath cells of $S$. australis. The ratio of mesophyll to bundle sheath cell numbers did not differ significantly, 

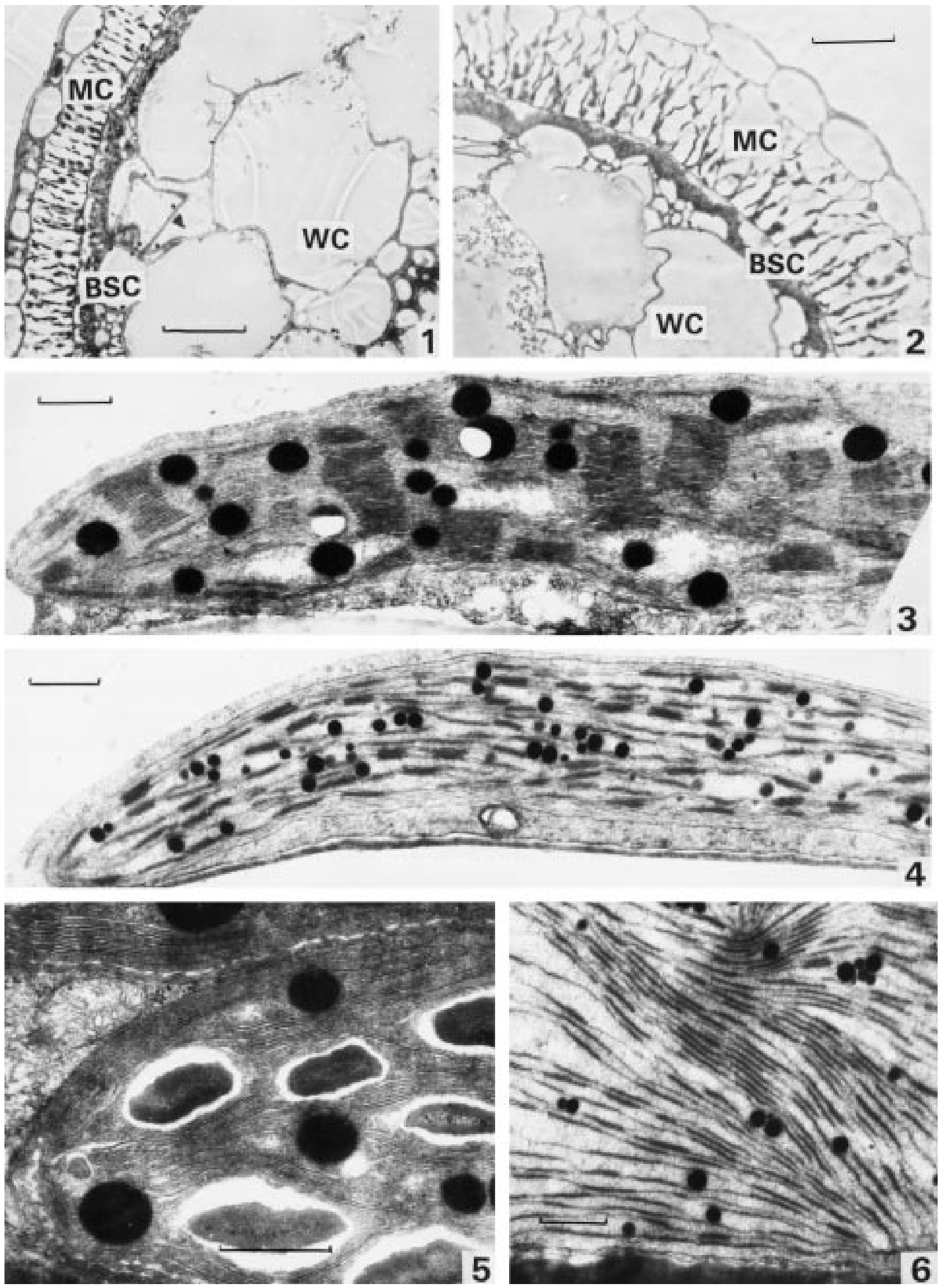
TABLE 1. The number of thylakoids per granum, expressed as percentage of the total grana number per chloroplast, in three Salsola species.

\begin{tabular}{|c|c|c|c|c|c|c|c|}
\hline \multirow[b]{2}{*}{ Species } & \multirow{2}{*}{$\begin{array}{l}\text { Cell } \\
\text { type }\end{array}$} & \multicolumn{6}{|c|}{ Number of thylakoids per granum ${ }^{a}$} \\
\hline & & 2 & 3 & $4-5$ & $6-10$ & $11-20$ & $>21$ \\
\hline S. australis & $\mathbf{M}^{\mathrm{b}}$ & 33.1 & 16.1 & 15.3 & 17.8 & 12.8 & 4.9 \\
\hline$(1800 \mathrm{~m})$ & BS & 76.4 & 14.5 & 7.9 & 1.2 & - & - \\
\hline S. australis & M & 30.2 & 25.5 & 22.3 & 18.4 & 3.2 & 0.4 \\
\hline$(3860 \mathrm{~m})$ & BS & 89.1 & 10.2 & 0.7 & - & - & - \\
\hline S. oreophila & M & 22.6 & 21.3 & 25.3 & 24.9 & 5.9 & - \\
\hline$(1800 \mathrm{~m})$ & BS & 28.1 & 22.6 & 18.7 & 21.4 & 9.2 & - \\
\hline S. arbusculiformis & M & 30.6 & 50.6 & 16.1 & 2.7 & - & - \\
\hline$(500 \mathrm{~m})$ & BS & 22.5 & 33.6 & 36.2 & 6.5 & 1.2 & - \\
\hline
\end{tabular}

a From TEM data.

${ }^{\mathrm{b}} \mathrm{M}$ and $\mathrm{BS}=$ mesophyll and bundle sheath cells respectively.

3.9:1 and 4.7:1, in the two species from the same altitude (Table 3). In S. oreophila a high activity was measured for RuBPC, but only a low activity was detected for PEPC and NADP-ME (Table 3). Therefore, the structural and photosynthetic characteristics, e.g., the high membrane surfaces and granality, the low plastid concentration, and photosynthetic enzyme activities of $S$. oreophila are comparable to those of $\mathrm{C}_{3}$ plants (Tables 2, 3).

In the cylindrical leaf of $S$. arbusculiformis there also were 2-3 layers of palisade parenchyma around the leaf periphery. The vascular bundles were surrounded by small thin-walled sheath cells with a significant number of chloroplasts, which had no detectable orientation in the cell (Figs. 11-12). Although mesophyll chloroplasts are long and spindle-like, whereas the bundle sheath chloroplasts are roundish (Figs. 13-14), no large differences were noted between the cell types either in size, number of thylakoids or chloroplasts, or of chloroplast membrane surfaces (Tables 1-3). The mitochondria in bundle sheath cells were larger than in palisade cells, but without any detectable differences in their ultrastructure (Table 2). To our regret we have no data on enzyme activities in this species. With four Salsola species, namely, oreophila, montana, arbusculiformis, and pachyphylla, $\mathrm{C}_{3}$-like $\delta^{13} \mathrm{C}$ values were obtained; and samples from various regions in Middle Asia in various years all had $\mathrm{C}_{3}$ $\delta^{13} \mathrm{C}$ values (Table 4). Winter (1981) listed a $\mathrm{C}_{3}$-like $\delta^{13} \mathrm{C}$ value of $-26.9 \%$ o for a $S$. webbii specimen from Morocco. Therefore the combination of leaf structural data, $\delta^{13} \mathrm{C}$ values, and enzyme activities lead us to the conclusion that a small group of Salsola species conduct $\mathrm{C}_{3}$ photosynthesis. As an alternative, these species may conduct $\mathrm{C}_{3} / \mathrm{C}_{4}$ intermediate photosynthesis, but additional leaf studies, such as the $\mathrm{O}_{2}$ sensitivity of photosynthesis or $\mathrm{CO}_{2}$ compensation point values, must be conducted to assess this possibility.

\section{DISCUSSION}

$C_{4}$ photosynthetic structure and biochemistry-This study of leaf cell structure and chloroplast ultrastructure in the chlorenchyma of $S$. australis shows that it is a fairly typical $\mathrm{C}_{4}$ species, both when grown in middle and in high elevations. The enzyme activity work provides evidence that $S$. australis belongs to the malate-forming NADP-ME group of $\mathrm{C}_{4}$ photosynthesis plants independent of growth elevation. Interestingly, PEPC activity is lower than in Salsola species from hot deserts (P'yankov et al., 1991; P'yankov, Voznesenskaya, and Kondratschuk, 1993) and decreases with increasing altitude. In contrast, RuBPC and NADP-ME activities increase with altitude (Table 3).

Also some very interesting corollary data were ob-

TABLE 2. Size of chloroplasts and mitochondria and grana development in leaf cell types of three Salsola species.

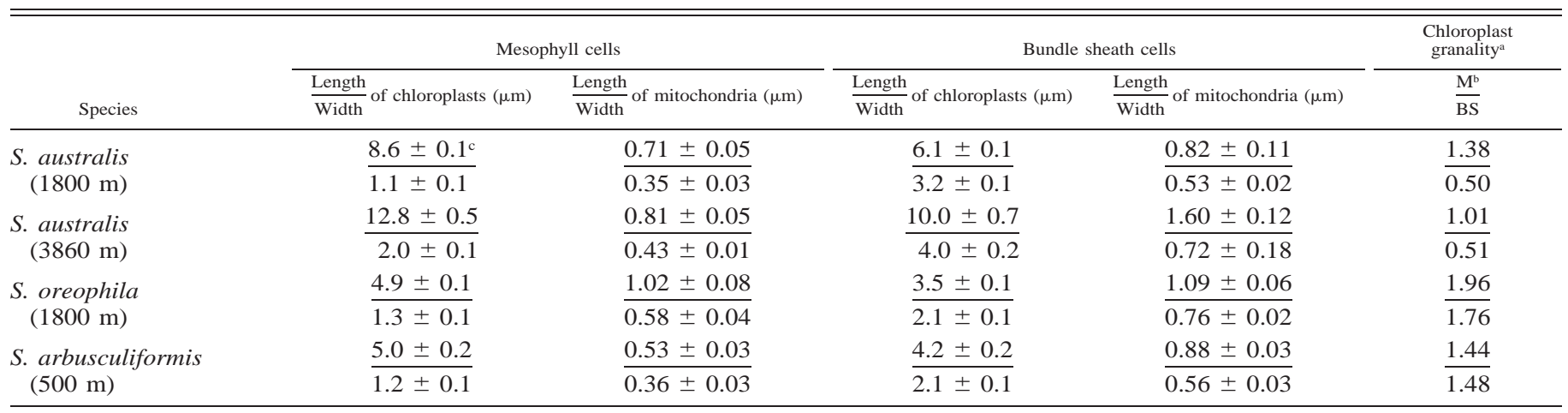

${ }^{a}$ Chloroplast granality $=$ the ratio of appressed thylakoid membrane length to the length of all nonappressed thylakoid membranes in the chloroplast.

${ }^{\mathrm{b}} \mathrm{M}$ and $\mathrm{BS}=$ mesophyll and bundle sheath cells, respectively.

${ }^{\mathrm{c}}$ From TEM data of 20 cross sections.

$\leftarrow$

Figs. 1-6. Light (LM) and TEM leaf microscopy of Salsola australis. For Figs. 1, 3, and 5 the plants were grown at $1800 \mathrm{~m}$ and for Figs. 2, 4, and 6 the plant were grown at $3860 \mathrm{~m}$. 1. Leaf in cross section (LM). Note two layers of chlorenchyma on the leaf periphery, i.e., the palisade mesophyll cells and roundish bundle sheath cells. $\times 150$. Bar $=100 \mu \mathrm{m}$. 2. Leaf in cross section $(\mathrm{LM})$. $\times 150$. Bar $=100 \mu \mathrm{m}$. 3. Portion of a mesophyll chloroplast $(\mathrm{TEM}) . \times 26000$. Bar $=0.5 \mu \mathrm{m}$. 4. Portion of a mesophyll chloroplast $(\mathrm{TEM}) . \times 25000$. Bar $=0.5 \mu \mathrm{m} .5$. Portion of a bundle sheath chloroplast $(\mathrm{TEM}) . \times 40000 . \mathrm{Bar}=0.5 \mu \mathrm{m}$. 6. Portion of a bundle sheath chloroplast $(\mathrm{TEM}) . \times 24000 . \mathrm{Bar}=0.5 \mu \mathrm{m} . \mathrm{BSC}=$ bundle sheath cells; $\mathrm{MC}=$ mesophyll cells; $\mathrm{WC}=$ water-storing cells. 
TABLE 3. Quantitative structural characteristics of the photosynthetic apparatus and enzyme activities in the cylindrical leaves of two Salsola species.

\begin{tabular}{|c|c|c|c|c|c|c|c|}
\hline \multirow[b]{2}{*}{ Characteristic } & \multirow{2}{*}{$\begin{array}{l}\text { Cell } \\
\text { type }\end{array}$} & \multicolumn{2}{|c|}{ S. oreophila } & \multicolumn{2}{|c|}{ S. australis } & \multicolumn{2}{|c|}{ S. australis } \\
\hline & & $1800 \mathrm{~m}$ & $\mathrm{M} / \mathrm{BS}^{\mathrm{a}}$ & $1800 \mathrm{~m}$ & $\mathrm{M} / \mathrm{BS}^{\mathrm{a}}$ & $3860 \mathrm{~m}$ & $\mathrm{M} / \mathrm{BS}^{\mathrm{a}}$ \\
\hline Leaf diameter $(\mu \mathrm{m})$ & - & 1144 & - & 1316 & - & 1142 & - \\
\hline Specific leaf mass $\left(\mathrm{mg} / \mathrm{dm}^{2}\right)$ & - & 987 & - & 1276 & - & 347 & - \\
\hline Cell volume $\left(\mu \mathrm{m}^{3}\right)$ & BS & 10.8 & - & 26.7 & - & 26.4 & - \\
\hline \multirow[t]{2}{*}{ Number of chloroplasts per cell } & M & 21 & 1.2 & 29 & 0.6 & 32 & 0.7 \\
\hline & BS & 18 & - & 45 & - & 47 & - \\
\hline Number of chloroplasts per $\mathrm{m}^{2}$ of leaf surface $\left(\times 10^{6}\right)$ & BS & 2 & - & 5.8 & - & 0.7 & - \\
\hline \multirow[t]{2}{*}{ Chloroplasts as a $\%$ of cell volume } & M & 4 & 0.5 & 20 & 0.8 & 21 & 1.1 \\
\hline & BS & 8 & - & 24.5 & - & 19.4 & - \\
\hline \multirow[t]{2}{*}{ Cell membrane surfaces $\left(\mathrm{m}^{2}\right.$ per $\mathrm{m}^{2}$ of leaf surface $)$} & M & 18.7 & 6.9 & 5.9 & 1.1 & 4.9 & 4.5 \\
\hline & BS & 2.7 & - & 5.4 & - & 1.1 & \\
\hline Outer chloroplast membrane surfaces $\left(\mathrm{m}^{2}\right.$ per $\mathrm{m}^{2}$ of leaf surface) & $\mathrm{M}$ & 4.3 & 0.8 & 15.3 & 1.9 & 1.8 & 3.0 \\
\hline PEPC & - & 0.2 & - & 1.6 & - & 1.1 & - \\
\hline NADP-ME & - & 0.3 & - & 1.2 & - & 2.8 & - \\
\hline
\end{tabular}

${ }^{\mathrm{a}} \mathrm{M}$ and $\mathrm{BS}=$ mesophyll and bundle sheath cells, respectively.

${ }^{b}$ Values are for total leaf extracts.

TABLE 4. Leaf carbon isotope fractionation values in Salsola species from various regions in the former USSR.

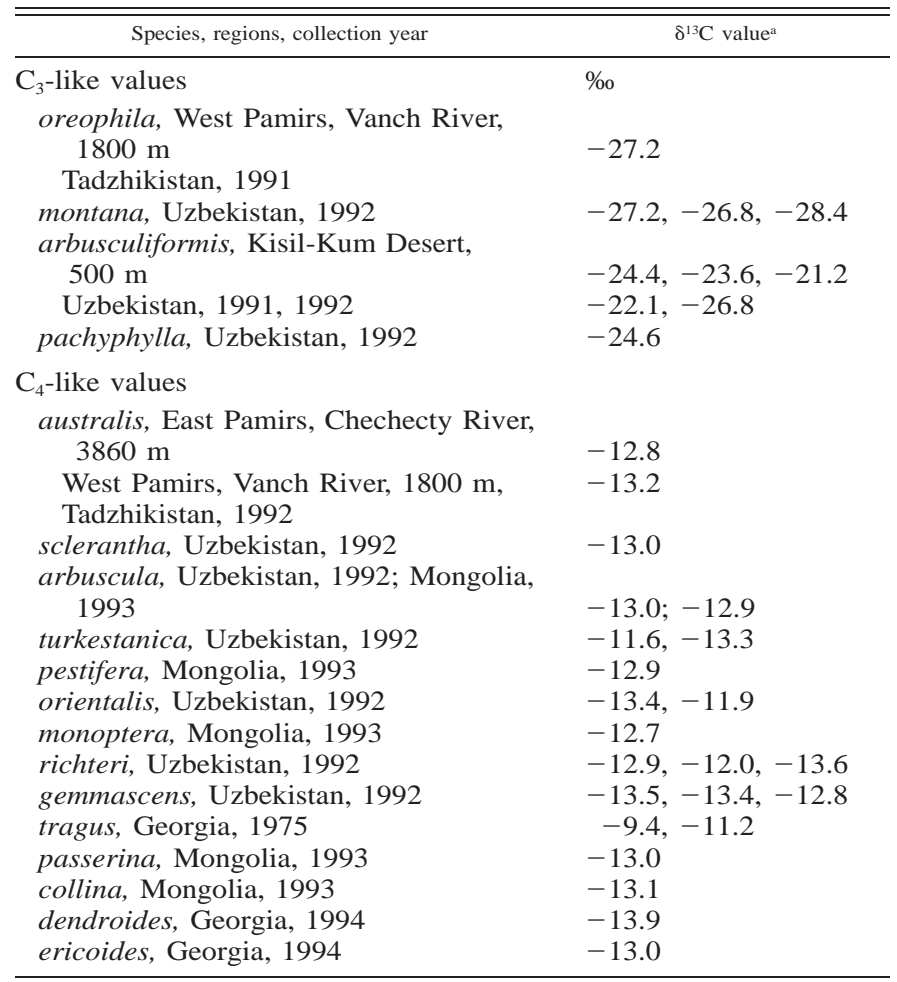

${ }^{a}$ Each value is for a separate collection specimen. tained earlier during a comparative study of the $\mathrm{C}_{4}$ plant $S$. australis with two high-mountain $\mathrm{C}_{3}$ species (P'yankov et al., 1993). It was shown that the $\mathrm{C}_{3}$ Bassia dasyphylla, which has the Sympegmoid type of leaf structure, had a level of RuBPC activity typical of $\mathrm{C}_{3}$ plants, while the activities of PEPC and NADP-ME were practically undectable. In the $\mathrm{C}_{3} S$. oreophila the activities of $\mathrm{C}_{4}$ enzymes were low but detectable, however the level of RuBPC was half that in B. dasyphylla, but double that in S. australis.

It is known that low temperatures are associated with an increase in the level of RuBPC (Pearcy, 1977) and a suppression of $\mathrm{C}_{4}$ metabolism occurs ( $\mathrm{P}^{\prime}$ yankov, 1984). It was observed that the RuBPC/PEPC ratio was altered in the $\mathrm{C}_{4}$ plant Eleusine coracana grown at different altitudes, which is connected with an increased activity of RuBPC and a decreased PEPC (Pandey and Purohit, 1980). We have the same results in $S$. australis from different altitudes (Table 3 ) and believe that the main reason for this is that there is a temperature decrease associated with an increase in altitude that would favor $\mathrm{C}_{3}$ photosynthesis. Even so, we readily found some $\mathrm{C}_{4}$ Salsola growing naturally at $4000 \mathrm{~m}$ and the $\delta^{13} \mathrm{C}$ values (Table 4) were clearly $\mathrm{C}_{4}$ at both growth altitudes.

$C_{3}$ photosynthetic structure and biochemistry-Our leaf ultrastructural work shows the presence of green bundle sheath cells in $S$. oreophila and S. arbusculiformis, but their characteristics are rather similar to those of the ordinary bundle sheaths in many $C_{3}$ species and different from typical bundle sheath cells of $\mathrm{C}_{4}$ species (because they lack the thickening of bundle sheath cell walls, the chloroplasts in these cells were not numerous, and a dimorphism of mesophyll and bundle sheath chloroplasts was absent). It was noted that one of these species, $S$. 

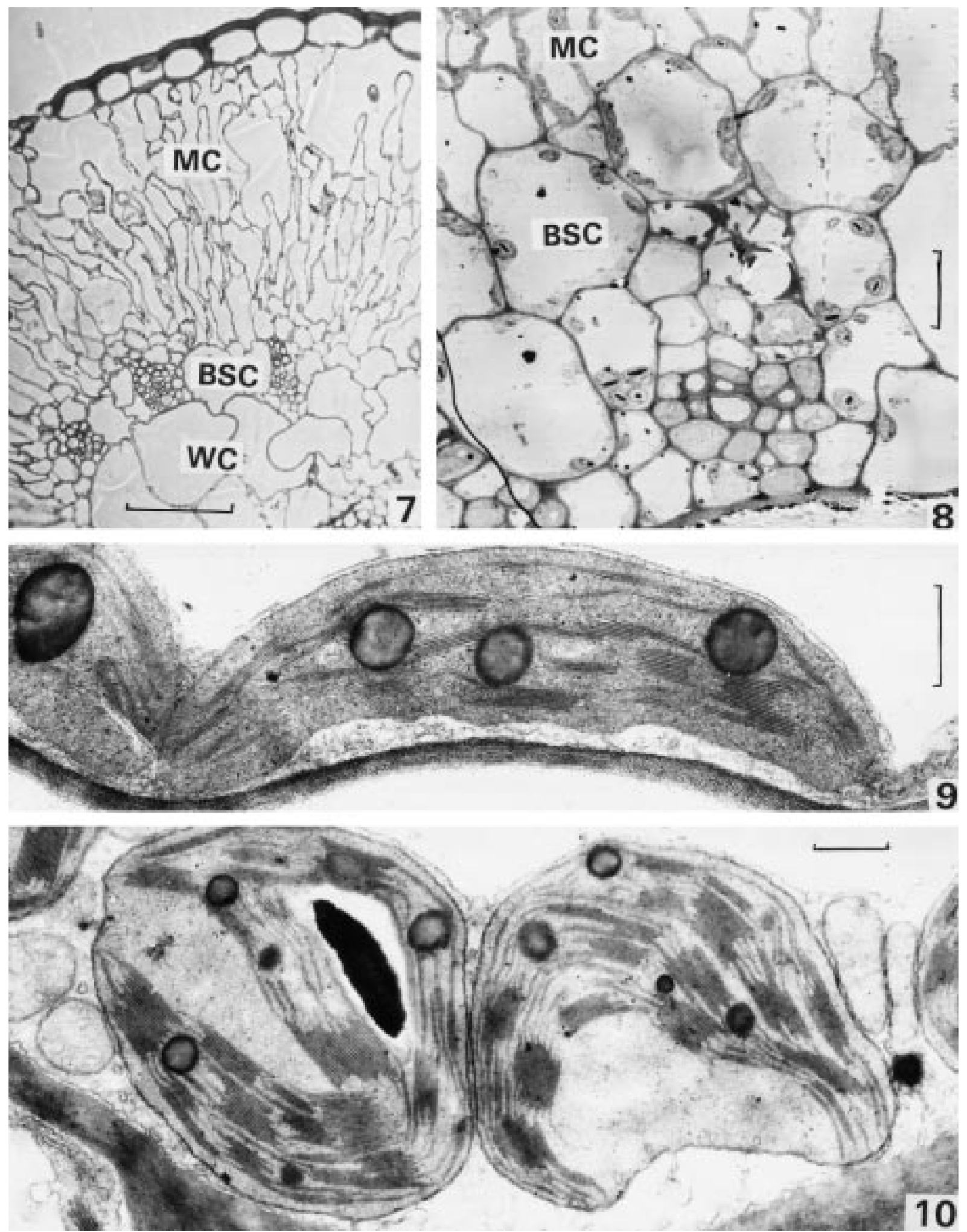

Figs. 7-10. Light and TEM leaf microscopy of Salsola oreophila from $1800 \mathrm{~m}$. 7. Leaf in cross section (LM). $\times 180$. Bar $=100 \mu \mathrm{m} .8$. Note the minor peripheral vascular bundle surrounded by parenchymatous bundle sheath cells $($ TEM). $\times 1300$. Bar $=10 \mu$ m. 9. A mesophyll chloroplast (TEM). $\times 35000$. Bar $=0.5 \mu \mathrm{m}$. 10. Portion of a bundle sheath cell with chloroplasts and mitochondria $(\mathrm{TEM}) . \times 25000$. Bar $=0.5 \mu \mathrm{m}$. 

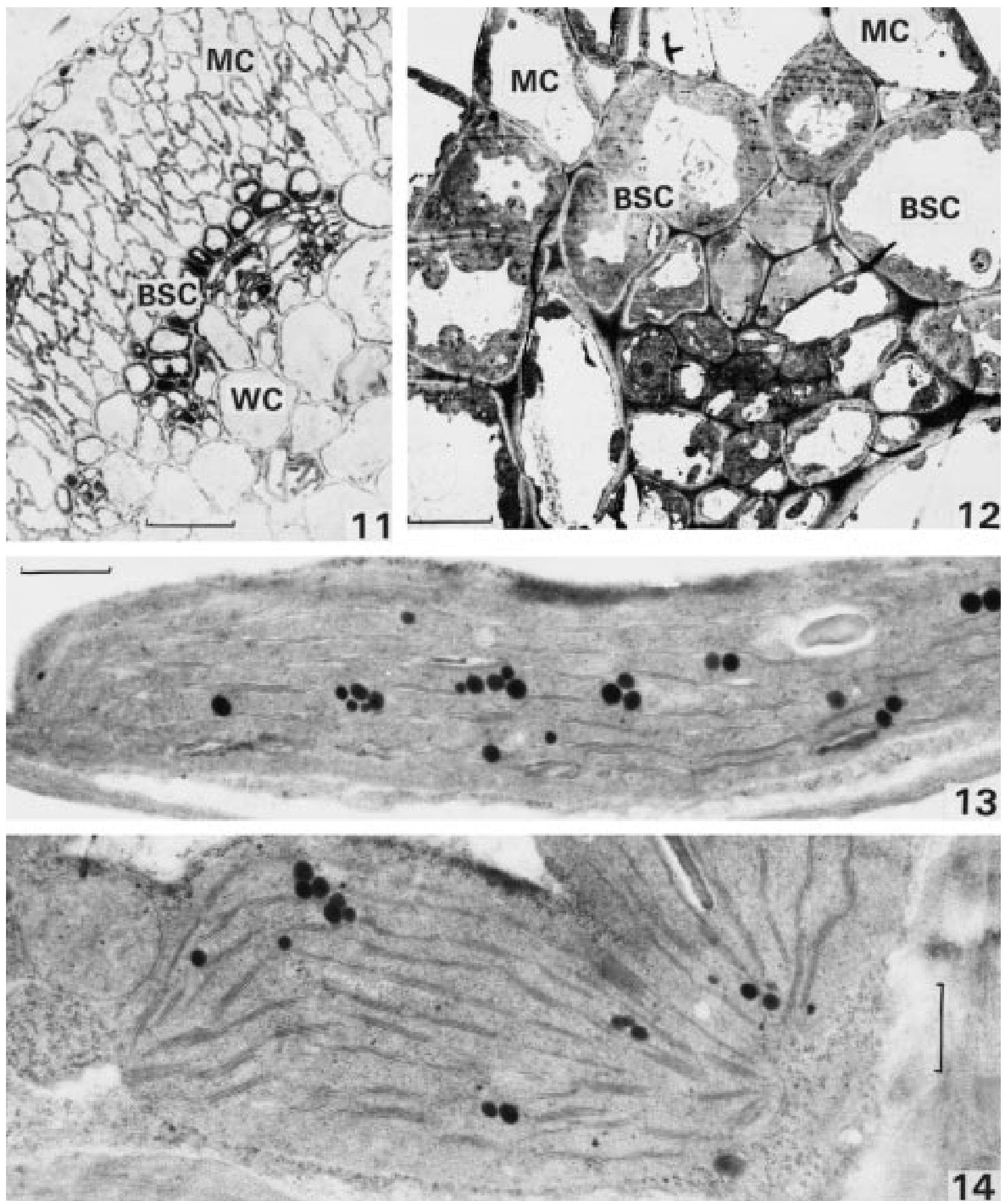

Figs. 11-14. Light and TEM leaf microscopy of Salsola arbusculiformis from $500 \mathrm{~m}$. 11. Leaf cross section $(\mathrm{LM}) . \times 150 . \mathrm{Bar}=100 \mu \mathrm{m}$. 12. Note the minor peripheral vascular bundle surrounded by parenchymatous bundle sheath cells $($ TEM). $\times 1400$. Bar $=10 \mu \mathrm{m}$. 13. A mesophyll chloroplast $(\mathrm{TEM}) . \times 30000 . \mathrm{Bar}=0.5 \mu \mathrm{m}$. 14. A bundle sheath chloroplast and mitochondrion $(\mathrm{TEM}) . \times 30000 . \mathrm{Bar}=0.5 \mu \mathrm{m}$. 


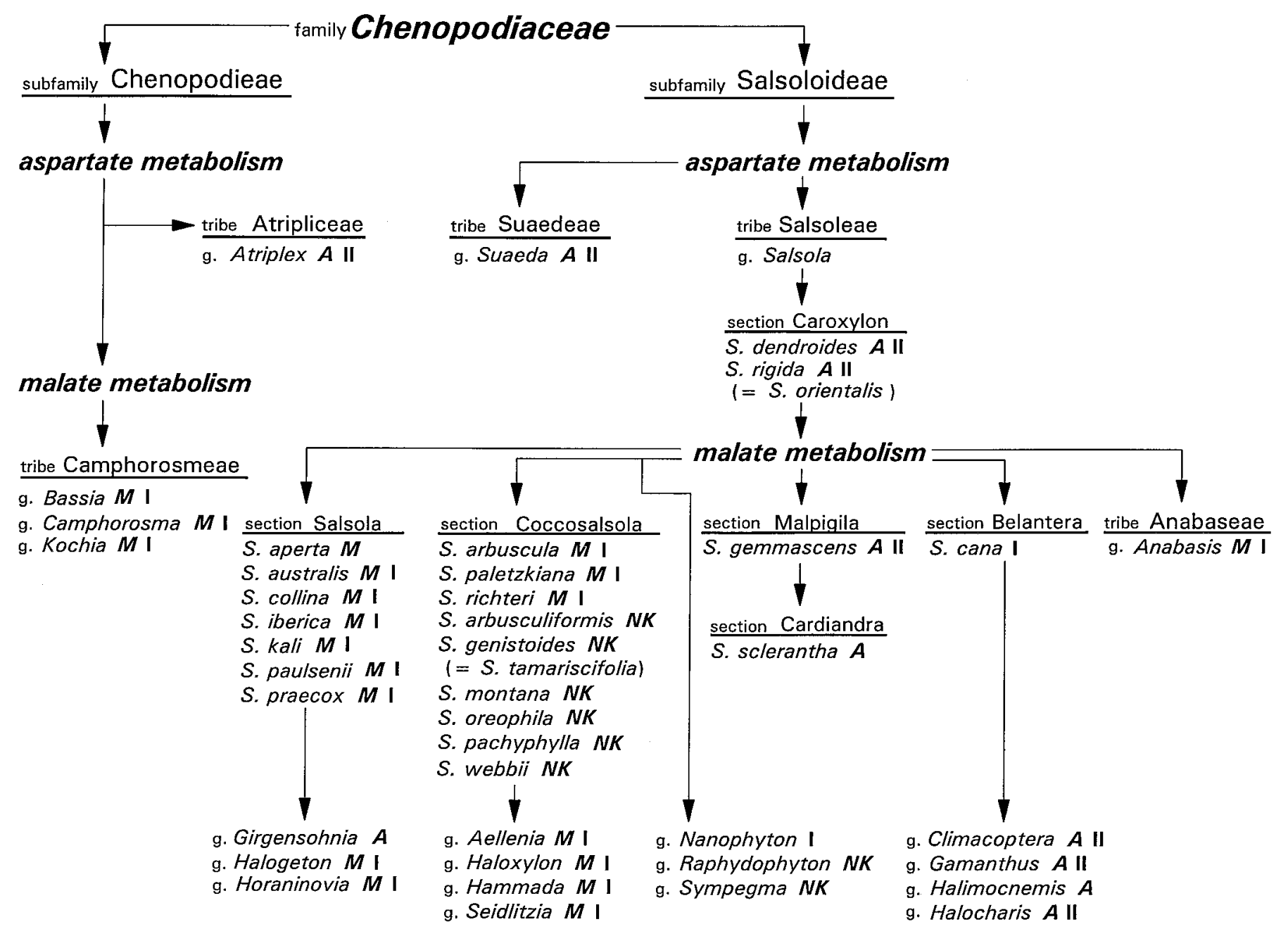

Fig. 15. Scheme for the evolution of Chenopodiaceae based on the biochemistry of photosynthetic carbon metabolism, leaf cellular structure, and ultrastructural features of their photoassimilating apparatus. $\mathrm{M}$ and $\mathrm{A}=$ two types of $\mathrm{C}_{4}$ photosynthesis species, namely: $\mathrm{M}=$ primarily malate forming, containing NADP-ME; and $\mathrm{A}=$ primarily aspartate forming, containing NAD-ME. $\mathrm{C}_{3}=\mathrm{C}_{3}$ type of photosynthesis. $\mathrm{S}$. $=$ Salsola; $\mathrm{g}$. $=$ genus. Structural types: I = grana reduction in bundle sheath cells with chloroplast dimorphism; II = bundle sheath cells with granal chloroplasts and specialized mitochondria. NK = nonKranz type, in these cases, Sympegmoid according to Carolin, Jacobs, and Vesk (1975). The structural and biochemical features used to compose this scheme were collated from Gedemov, 1974; Gutierrez, Gracen, and Edwards, 1974; Olesen, 1974; Carolin, Jacobs, and Vesk, 1975; Voznesenskaya, 1976a, b; Butnik, 1984; Gamaley, 1985; Voznesenskaya and Gamaley, 1986, 1988; Piankov and Vakhrusheva, 1989; Glagoleva et al., 1990, 1992; Piankov et al., 1992a, b; P'yankov, Voznesenskaya, and Kondratschuk, 1993.

oreophila, had a centrifugal position of bundle sheath chloroplasts, more typical of $\mathrm{C}_{3}$ plants, but $S$. arbusculiformis had no dominant orientation of its chloroplasts. Only small differences could be detected in mesophyll vs. bundle sheath chloroplast ultrastructure in either species. The high RuBPC but low PEPC and NADP-ME activities also suggest that $S$. oreophila belongs to a group of $\mathrm{C}_{3}$ Salsola species. These data support the presence of a functional $\mathrm{C}_{3}$ cycle in both chlorenchyma cell types. We consider the low NADP-ME activity in $S$. oreophila a residual biochemical activity connected with this species' origin from malate-forming $\mathrm{C}_{4}$ Salsola.

Evolution of Chenopodiaceae and modifications in Salsola-A scheme to outline the evolution of the family Chenopodiaceae was developed on the basis of photosynthetic, biochemical, and structural characteristics (Fig. 15). The scheme also is based on the extensive systematic studies and ideas about the evolution of Salsola of Botschantzev (1969, 1976). Botschantzev (1969) suggested that the genus Salsola appeared not later than the Miocene in South Africa in the form of one section, Caroxylon (Thunb.) Fenzl. Then, this ancient section was distributed to the Red Sea district where extensive genus formation took place. Also, the South Africa center was cut off later from the Red Sea center by the zone of tropical forests in Africa. Therefore, in South Africa today Salsola species exist with ancient characteristics.

The most ancient, initial species in the genus Salsola were bushes, growing preferentially on rocks, crushed stones, or other ancient substrates. The young derivatives today are annual species. The first derivatives of the section Caroxylon were the sections Malpigila and Belantera and the tribe Anabaseae (Fig. 15), which appeared in the Pliocene in the Red Sea center of genus formation (Bot- 
schantzev, 1969). The section Belantera is a derivative of Caroxylon (Fig. 15), and the evolution in this section went from shrubs via semishrubs to annuals.

Then three main sections appeared: Arbuscula, which includes shrubs and semishrubs; Coccosalsola with shrubs and annuals; and Salsola with annuals. Littoral species, such as Salsola kali L, are only in the last, the youngest section. In later years Botschantzev (1976) reviewed the composition of Coccosalsola and included in it the species of the section Arbuscula as a subsection. Botschantzev (1969) also noted that the evolution of the genus Salsola and the tribes Salsoleae and Anabaseae proceeded in several ways: tree to shrub to herb, shrub to shrub, and herb to herb. Thus not only annuals appeared on young sandy and loessy spaces, but also "young" shrubs, e.g., Salsola paletzkiana Litv. on sands.

It is a great pity that we do not have any representatives of ancient species in the section Caroxylon from South Africa for our study, but all species studied so far have typical Salsoloid-type Kranz anatomy, NAD-ME type of $\mathrm{C}_{4}$ photosynthesis, and the II type of ultrastructure, as does $S$. gemmascens from the section Malpigila (Fig. 15). Only the youngest and most advanced species from Coccosalsola and Salsola sections have an NADP-ME type of biochemistry and the I type of chloroplant ultrastructure (Fig. 15). Note that this sequence of $\mathrm{C}_{4}$ evolution also corresponds to that of some $\mathrm{C}_{4}$ grasses, which have the NADP-ME type of photosynthesis together with bundle sheath chloroplasts with reduced grana, e.g., in the most advanced Andropogoneae tribe (Brown, 1958; Downton, and Tregunna, 1968).

All Salsola species with the Sympegmoid-type structure studied so far, such as S. webbii (Carolin, Jacobs, and Vesk, 1975), S. tamariscifolia (Voznesenskaya, 1976b), S. arbusculiformis (Rojanovskii, 1970; Butnik, 1984), and S. montana and S. pachyphylla (Butnik, 1984) belong to one of the most advanced sections of Salsola, Coccosalsola (Botschantzev, 1976). This section presumably is derived from the most ancient section, Caroxylon (Botschantzev 1969, 1976) in which all species studied have typical Salsoloid-type $\mathrm{Kranz}$ anatomy and $\mathrm{C}_{4}$ photosynthesis. The genera Sympegma (Carolin, Jacobs, and Vesk, 1975) and Raphydophyton (Butnik, 1984) also have similar leaf anatomy and originate from an ancient branch-like section Coccosalsola (Pratov, 1987). Butnik (1984) claimed the species she described had $\mathrm{C}_{4} \mathrm{Kranz}$ anatomy; nevertheless our work does not support this claim. We believe that all of the species and some members of the genera mentioned above have the Sympegmoid type of nonKranz leaf structure (see NK designations in Fig. 15). If this is so, even the time of origin of section Coccosalsola (and species with a Sympegmoid type of anatomy) must have occurred recently in relation to Salsola species with the $\mathrm{C}_{4}$ syndrome. The existence of this type of leaf anatomy in two branches of the family Chenopodiaceae is a good example of parallel evolution. Also it is very interesting that they are shrubs or semishrubs or annuals, and the section Coccosalsola also contains species such as $S$. paletzkiana and $S$. richteri, which are shrubs growing in sandy deserts. According to Botschantzev (1969) these species are rather young in the succession of Salsola.

It is believed that at the end of the Tertiary period in
Pliocene, there were orogenic processes in Asia followed by sharp climatic differentiations, which included the territories in the modern Pamirs, Tien Shan, and Djungaria, where Salsola genera are widely distributed (Botschantzev 1969). A most probable way to adapt to the cooler climatic conditions was to suppress the thermophilic $\mathrm{C}_{4}$ photosynthesis biochemistry and return to a more coolstable $\mathrm{C}_{3}$ type of $\mathrm{CO}_{2}$ fixation, which would allow them to occupy new cooler ecological niches. Therefore $S$. oreophila can grow in the Eastern Pamirs at altitudes of $3000-3700 \mathrm{~m}$ and play a role as a major plant in those high mountain deserts (Ikonnikov, 1979). Some $\mathrm{C}_{4} \mathrm{Che-}$ nopodiaceae species were discovered in this district at altitudes up to $4000 \mathrm{~m}$ (P'yankov, 1990), but they are not dominant components of the vegetation. Indeed they seem rather ruderal and alien.

In brief, the results we obtained extend and support the hypothesis of Carolin, Jacobs, and Vesk (1975) that the most likely origin of a $\mathrm{C}_{3}$ Sympegmoid nonKranz leaf structure was as a result of a reversion of the Salsoloid Kranz type leaf anatomy from a $\mathrm{C}_{4}$ to a $\mathrm{C}_{3}$ photosynthesis. Our hypothesis is that this reversion process in Salsola was connected in the first place with the reduction of biochemical systems for the $\mathrm{C}_{4}$ dicarboxylic acid cycle and then with changes in anatomical features of the photosynthetic tissues.

\section{LITERATURE CITED}

Bender, M. M., I. Rouhani, H. M. Vines, and C. C. Black, Jr. 1973. ${ }^{13} \mathrm{C} /{ }^{12} \mathrm{C}$ ratio changes in Crassulacean acid metabolism. Plant Physiology 52: 427-430.

BotschantzeV, V. P. 1969. The genus Salsola L. (composition, history of development and distribution). Summary of report on published papers presented instead of doctor degree thesis. Nauka, Leningrad (in Russian).

- 1976. Review of species of Coccosalsola Fenzl section of genus Salsola L. News Systematics Higher Plants 13: 74-102 (in Russian).

Brown, W. V. 1958. Leaf anatomy in grass systematics. Botanical Gazette 119: 170-178.

Butnik, A. A. 1984. The adaptation of anatomical structure of the family Chenopodiaceae Vent. species to arid conditions. Summary of biological science doctor degree thesis. Academy of Science Uzbekistan (Tashkent) (in Russian).

Campbell, W. H., and C. C. Black. 1982. Cellular aspects of $\mathrm{C}_{4}$ leaf metabolism. Recent Advances in Phytochemistry 16: 223-248.

Carolin, R. C., S. W. L. Jacobs, AND M. Vesk. 1975. Leaf structure in Chenopodiaceae. Botanishe Jahrblcher für Systematishe Pflanzengeschichte und Pflanzengeographie 95: 226-255.

Downton, W. J. S., And E. B. Tregunna. 1968. Carbon dioxide compensation-its relation to photosynthetic carboxylation reactions, systematics of the Gramineae, and leaf anatomy. Canadian Journal of Botany 46: 207-215.

Gamaley, Y. V. 1985. The variations of the Kranz-anatomy in Goby and Karakum plants. Botanicheskii Zhurnal 70: 1302-1314 (in Russian with English summary).

- - AND E. V. VOZNESENSKAYA. 1986. Structural and biochemical types of $\mathrm{C}_{4}$-plants. Fisiologiya rastenii 33: 802-819 (in Russian with English summary).

Gedemov, T. 1974. The study of the ways of carbon dioxide fixation and metabolism during the photosynthesis in South-East Karakum plants. Summary of biological science candidate degree thesis. Nauka, Leningrad (in Russian).

Glagoleva, T. A., M. V. Chulanovskaya, M. V. Pakhomova, E. V. VozNESENSKAyA, AND Y. V. GAMALEY. 1992. Effect of salinity on the structure of assimilating organs and ${ }^{14} \mathrm{C}$ labelling patterns in $\mathrm{C}_{3}$ and $\mathrm{C}_{4}$ plants of Ararat plain. Photosynthetica 26: 363-369.

, E. V. Voznesenskaya, K. G. Kolchevsky, N. I. Kocharyan, 
M. V. Pakhomova, M. V. Chulanovskaya, and Y. V. Gamaley. 1990. Structural and functional characteristics of halophytes from the Ararat valley. Fisiologiya rastenii 37: 1080-1088 (in Russian with English summary).

Gutierrez, M., Y. E. Gracen, AND G. E. Edwards. 1974. Biochemical and cytological relationships in $\mathrm{C}_{4}$-plants. Planta 119: 279-300.

IкоNNIKov, S. S. 1979. Definitorium Plantarum Vascularium Badachschaniae. Nauka, Leningrad (in Russian).

Ku, S. B., Y. J. Shieh, B. J. Reger, and C. C. Black. 1981. Photosynthetic characteristics of Portulaca grandiflora, a succulent $\mathrm{C}_{4}$ dicot. Plant Physiology 68: 1073-1080.

Mokronosov, A. T. 1981. The ontogenetic aspects of photosynthesis. Nauka, Moscow (in Russian).

Olesen, P. 1974. Leaf anatomy and ultrastructure of chloroplasts in Salsola kali L. as related to the $\mathrm{C}_{4}$-pathway of photosynthesis. Bot. Notiser 127: 352-363.

Pandey, O. P., And A. N. Purohit. 1980. Activity of PEP-carboxylase and two glycolate pathway enzymes in $\mathrm{C}_{3}$ and $\mathrm{C}_{4}$ plant grown at two altitudes. Current Science 49: 263-265.

Pearcy, R. W. 1977. Acclimation of photosynthetic and respiratory carbon dioxide exchange to growth temperature in Atriplex lentiformis (Torr.) Wats. Plant Physiology 59: 795-799.

Piankov, V. I., AND D. V. VAKhrusheVA. 1989. The pathways of primary $\mathrm{CO}_{2}$ fixation in Chenopodiaceae $\mathrm{C}_{4}$-plants of Central Asian arid zone. Fisiologiya rastenii 36: 228-238 (in Russian with English summary).

, E. V. Voznesenskaya, A. N. Kuz'min, E. D. Demidov, and A. I. MAsLov. 1992a. Diverse biochemical pathways of $\mathrm{CO}_{2}$ fixation by some plants of the Poaceae and the Chenopodiaceae family growing in the arid region of Central Asia. Fisiologiya rastenii, 39: 645-657 (in Russian with English summary).

A. A. VAsiliev, AND O A. DzYUBENKo. 1992b. $\mathrm{C}_{4}$-photosynthesis in alpine species of the Pamirs. Fisiologiya rastenii 39: 658-670 (in Russian with English summary).

Pratov U. 1987. Chenopodiaceae Vent. of the Middle Asia and the Northern Africa (systematics, phylogenesis and botanical-geography analysis). Summary of biol. science doctor degree thesis. Academy of Sciences USSR, Leningrad (in Russian).

P'YANKOV, V. I. 1984. Relationship between primary $\mathrm{CO}_{2}$ fixation pathways in $\mathrm{C}_{4}$-plants of arid zones as affected by various temperature. Fisiologiya rastenii 31: 826-832 (in Russian with English summary).

. 1990. Evolution and ecological importance of $\mathrm{C}_{4}$-plants in arid zone of Middle Asia. Soviet-India symposium on: regulation of photosynthesis, 22-23. Pushchino, Russia.

- 1991. The origin and evolution of $\mathrm{C}_{4}$ metabolism of the Chenopodiaceae as a result of global aridization of climate. In Impact of global climatic changes on photosynthesis and plant productivity, 711-720. Oxford \& IBH Publishing CO. PVT LTD., New Dehli.

, A. N. Kuz'min, E. D. Demidov, and A. J. Maslov. 1991. Biochemical types of photosynthesis in $\mathrm{C}_{4}$-plants of the arid zone of Middle Asia. Doklady Akademii Nauk USSR 38: 509-512 (in Russian)

-, E. V. Voznesenskaya, And A. V. Kondratschuk. 1993. Structural and biochemical features of the photosynthetic apparatus in the Pamirs high mountain succulent species of the family Chenopodiaceae with different types of $\mathrm{CO}_{2}$ fixation. Tsitologiya 39: 3038 (in Russian with English summary).

- A. N. KuZ'Min, E. D. Demidov, AND O. A. Dzyubenko. 1993. The comparative characterization of photosynthetic apparatus of Chenopodiaceae $\mathrm{C}_{4}$-plants of the Pamirs high mountains and arid zone of Middle Asia. Botanicheskii Zhurnal 78: 45-58 (in Russian with English summary).

RojanovskiI, S. Y. 1970. The anatomical peculiarities of Salsola arbuscula Pall. and Salsola arbusculiformis Drob. leaves as a specific diagnostic features. In Materials on structural and functional peculiarities of useful wildgrowing plants of Uzbekistan. Academy of Science Uzbekistan (Tashkent) 7-10 (in Russian).

Shomer-Ilan, A., S. BeER, AND Y. WaIsel. 1975. Suaeda monoica, a $\mathrm{C}_{4}$ plant without typical bundle sheaths. Plant Physiol. 56: 676679 .

VOZNESENSKAYA, E. V. 1976a. Ultrastructure of assimilating organs of some species of the family Chenopodiaceae. I. Botanicheskii Zhurnal 61: 342-351 (in Russia with English summary).

- 1976b. The ultrastructure of assimilating organs of some species of the family Chenopodiaceae. II. Botanicheskii Zhurnal 61: 1546-1557 (in Russian with English summary).

, AND Y. V. GAMALEY. 1986. The ultrastructural characteristics of leaf types with Kranz anatomy. Botanicheskii Zhurnal 71: 12911307 (in Russian with English summary).

, AND - 1988. The mesophyll ultrastructure of the Armenian $\mathrm{C}_{4}$-species. Plant ultrastructure, Abstracts VI symposium, Kiev (in Russian).

WinTER, K. 1981. C 4 plants of high biomass in arid regions of Asia: occurrence of $\mathrm{C}_{4}$ photosynthesis in Chenopodiaceae and Polygonaceae from the Middle East and USSR. Oecologia 48: 100-106.

ZalenskiI, O. V., and T. A. Glagolevan. 1981. Pathway of carbon metabolism in halophytic desert species from Chenopodiaceae. Photosynthetica 15: 244-255. 